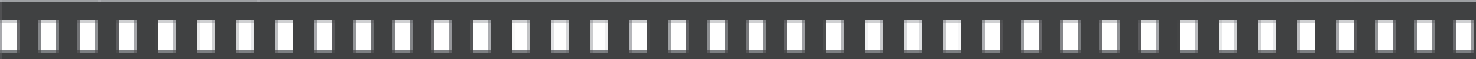

\section{Tempo revelado: fotojornalismo e construçãa de sentidos}

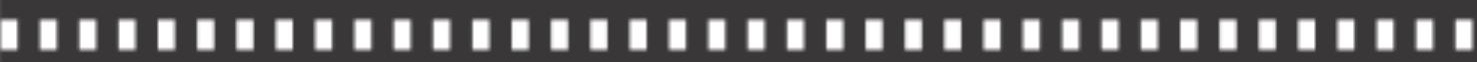

\section{Gutemberg Medeiros}

Artigo recebido em: 31/08/2012

Artigo aprovado em: 14/02/2013 


\section{Tempo revelado: fotojornalismo e construção de sentidos}

Time revealed: photojournalism and the construction of meanings

Gutemberg Medeiros*

Resumo: Este trabalho levanta aspectos de como o fotojornalismo já tinha o mesmo patamar de importância comunicacional que a reportagem desde o início do século $X X$. O fotojornalismo surge como um dos elementos fundantes da Modernidade, que é para ser vista ou lida como discurso não verbal. Trazemos elementos para verificar como estes textos não verbais trazem importante contribuição na construção de sentidos de um tempo e lugar a partir de objetos midiáticos do jornalismo impresso, na arquitetura de uma memória.

Palavras-chave: Jornalismo moderno. Modernidade. João do Rio. Fotojornalismo e memória.

Abstract: This article proposes raising aspects of how photojournalism has had the same level of importance that the communication from the beginning of the modern journalism in early $X X$ century. The photojournalism arises in this scenario as a key foundational elements of Modernity, to be seen or read as nonverbal discourse. We bring these elements to see how nonverbal texts in important contribution in the construction of meaning in a particular time and place media objects from print journalism, in the architecture of a memory.

Keywords: Modern journalism. Modernity. João do Rio. Photojournalism and memory.

* Doutor pela Escola de Comunicações e Artes da Universidade de São Paulo (ECA/USP). Pesquisador filiado ao Grupo de Estudos do Livro e da Edição da ECA/USP. E-mail: gam8@terra.com.br 


\section{Introdução}

A primeira década do século XX foi decisiva para a Modernidade no Brasil, pois vários de seus elementos aqui aportaram e se impuseram em flagrante atraso em relação às suas matrizes norte-americana $\mathrm{e}$ europeia. Em nossa tese de doutorado (MEDEIROS, 2009), verificamos que braços dessa Modernidade se estabeleceram ao mesmo tempo na implantação de um moderno jornalismo e da grande reforma urbana do Rio de Janeiro - então capital federal - movimento este mais conhecido como "bota-abaixo".

Entre outros elementos, o que surpreende é como o cânone expresso desse moderno jornalismo está lastreado em caráter "informativo" e quase explicitando a prioridade em torno da objetividade e imparcialidade. Impressionante porque esses eram os elementos primordiais do jornalismo norte-americano implantado a partir dos anos de 1950 no Brasil e matriz do que é exercido no espaço midiático até hoje.

Neste ensaio, em parte derivado de nossa tese de doutorado, trazemos elementos para verificar como o fotojornalismo e a matéria jornalística - textos verbais e não verbais - têm a mesma importância no ato comunicacional e trazem importantes contribuições na arquitetura de uma memória que subsidia a historiografia enquanto material primário.

Neste sentido, iniciamos com uma matéria publicada em 1907 no jornal carioca Gazeta de Notícias - um dos maiores do país e introdutor do jornalismo moderno no Brasil. Entre outros valores expressos dessa etapa inovadora do jornal, dá o devido peso ao fotojornalismo nesta nova ordem de produção midiática.

Na sequência, abordamos uma matéria representativa da grande reforma do Rio de Janeiro, na qual se explicita o papel fulcral do fotojornalismo nas revistas ilustradas. Neste caso, a construção dessa memória não é apenas importante pelo que reporta explicitamente em palavras e imagens, mas igualmente pelo que silencia ou pressupõe em relação ao seu público leitor de determinado extrato da sociedade da época. 
Finalmente, como valor na informação fotográfica para o moderno jornalismo do início do século XX, a contribuição de João do Rio, um dos grandes agentes da implantação dessa nova fase da indústria da notícia no Brasil. Em crônica de 1916, ele defende a fotografia não apenas por estar na moda, mas como documento da realidade - sentimento comum entre os que faziam jornal na época.

\section{Memória cultural e modernidade}

Uma das bases de nossa reflexão lastreia-se na corrente de pensamento conhecida como semiótica da cultura de Tártu-Moscou, especialmente em um de seus mais importantes teóricos, Iuri Lotman. Para ele, todo o texto - verbal ou não verbal - cumpre a função de memória cultural de uma sociedade e a língua é a somatória do código e sua história, trazendo à tradução e transformação de sistemas de uma comunicação que, só aparentemente, reduz-se à simples transmissão de informação.

Lotman afirma que a cultura é inteligência e memória coletivas, mecanismo supraindividual de conservação e transmissão de determinados comunicados. Nesse sentido, o espaço da cultura é definido como o de certa memória comum, onde alguns textos podem ser conservados e atualizados.

Para nós, essa concepção de memória é muito importante ao abordamos sentidos expressos com o advento da fotografia na imprensa moderna. Porém, mantemos uma determinada ressalva lotmaniana: os sentidos na memória da cultura não se conservam, mas crescem. Afinal, a memória não é para a cultura um depósito passivo, mas compõe uma parte de seu mecanismo formador de textos. Em outras palavras, Lotman constituiu um processo dialógico bem próximo ao estudado por Bakhtin, mas estabelece novos parâmetros que são essenciais para o nosso propósito. 
Este trabalho constitui-se, inclusive, de um texto que se soma a uma multidão de outros textos - sejam verbais ou não verbais - que se somam à construção da memória cultural.

Modernité. O poeta Charles Baudelaire não foi o primeiro a usar o termo. Mas o inaugurou como um campo de preocupações que tomaram a era contemporânea. Para ele, o ser mais urbano possível, aquele que vê, busca e o que mais a revela

[...] este solitário dotado de uma imaginação activa, sempre viajando através do grande deserto de homens, tem um objetivo mais alto que o de um flâneur, um objetivo mais geral, que não o prazer fugidio da circunstância. Procura aquela qualquer coisa a que irão permitir-nos chamar a modernidade: porque não se nos depara melhor palavra para exprimir a ideia em questão. (BAUDELAIRE, 2006, p.289, grifo do autor).

Baudelaire não se ateve em fazer uma teorização sobre a Modernidade. O que se revela, ao longo de sua obra é:

[...] uma experiência estética, indissociável da actualidade da vida das grandes cidades, personificada no 'artista' (porta, criador) como 'homem do mundo' e 'homem das multidões', figura próxima do dandy e do flâneur, mas que não se confunde totalmente com eles. (LOURENÇO, 2006, p.17).

Ou, mais diretamente, "a modernidade parece ser um ponto de intersecção, sempre em movimento, entre o antigo e o novo, o eterno e o efêmero, que não passa necessariamente por uma antinomia entre eles". (LOURENÇO, 2006, p.17).

Revolução Industrial, metrópoles, adensamento populacional, circulação de mercadorias e de ideias, tecnologia, indústria da notícia e outros são elementos-chave do que é chamado de Modernidade. Todos compõem uma mesma realidade e são inter-relacionados sob um vetor específico: a velocidade. A sociedade moderna, a partir do final do século XVIII, passa a ser regida sob a égide do tempo, em detrimento da ordem anterior que privilegiava o espaço. 
A Modernidade apresenta-se como um grande texto, ou semiosfera ${ }^{1}$, que marca a contemporaneidade. Para efeito desse trabalho, nos vinculamos ao filósofo francês Henri Lefebvre que compreende a Modernidade como um metatexto de si própria:

Por 'Modernidade' nós compreendemos, ao contrário, uma reflexão principiante, um esbôço mais ou menos adiantado de crítica e de autocrítica, uma tentativa de conhecimento. Nós o alcançamos numa série de textos e de documentos, que trazem a marca de sua época e entretanto ultrapassam a incitação da moda e a excitação da novidade. A Modernidade difere do Modernismo como um conceito em via de formulação na sociedade difere dos fenômenos sociais, como uma reflexão difere dos fatos. (LEFEBVRE, 1969, p.4).

Aqui, entendemos a Modernidade como uma era, um momento histórico que se desenrola a partir da Revolução Industrial do final do século XVII até meados do século XX, quando se inicia o esboço do que viria a ser chamado de pós-modernidade. No correr desse ensaio, arrolamos outros elementos do que entendemos de Modernidade, desde que dialogando diretamente com os objetos midiáticos em questão.

\footnotetext{
${ }^{1}$ A semiosfera foi um conceito elaborado por Iuri Lotman, a partir de artigo publicado originalmente em 1984, para expressar um determinado espaço semiótico e a relação espaço-temporal entre diversos textos ou sistemas sígnicos que o compõe. A semiosfera é um continuum semiótico de textos ou objetos ou formações semióticas de vários tipos e níveis de organização. (LOTMAN, 1996, p.22). Como um conjunto de diferentes textos e linguagens, fechados uns em relação aos outros, este espaço semiótico pode ser considerado como um mecanismo único, senão como um organismo. Seja composta de textos em linguagens verbais e/ou não-verbais, a semiosfera é caracterizada por elementos específicos: delimitação e irregularidade semiótica. O caráter delimitado determina homogeneidade e individualidade semióticas. A delimitação deste "organismo é posicionada pela fronteira semiótica, a soma dos tradutores - filtros bilíngües através dos quais um texto se traduz a outra linguagem (ou linguagens) que se fará fora da semiosfera dada". (LOTMAN, 1996, p.24). Um de seus conceitos mais importantes da semiosfera é o de fronteira, pois une duas esferas da semiosis, desde a autoconsciência semiótica - autodescrição em um metanível da semiosfera dada. (LOTMAN, 1996, p.28). A fronteira é um domínio de processos semióticos acelerados que ocorrem mais na periferia e se dirige às estruturas nucleares para, possivelmente, desalojá-las.
} 


\section{Jornal pela voz do jornal}

O moderno jornalismo se estabeleceu definitivamente, na imprensa brasileira, em 1907. Ele se constituiu pelo emprego de novas modalidades de textos para veicular notícias ou privilegiar informações derivadas de reportagens de campo e compostos em títulos em letras garrafais, intertítulos, charges, ilustrações e vinhetas. Era impresso em gráficas com os mais recentes recursos tecnológicos e modelo industrial de produção até o regime rígido de distribuição. Tudo sob a égide do tempo.

Nesse contexto, uma das prioridades era informar por meio de recursos imagéticos, cujo principal elemento foi o fotojornalismo. Aimagem estática conquistou a aura de sacralidade no jornalismo; ali residia uma verdade no ato de reportar.

Para se ter uma ideia de como esse processo teve um amplo impacto na sociedade da época, está a matéria "Como se faz um jornal de hoje", que não traz assinatura, apenas a logomarca de cunho institucional da Gazeta de Notícias - um dos maiores jornais do início do século XX, onde o escritor e jornalista João do Rio atuou por 12 anos e foi um dos principais colaboradores ao implantar o modelo mais bem acabado de reportagem no país. Publicada em 2 de agosto de 1907, a matéria é construída na primeira pessoa do plural, quando o mais comum era o uso da terceira pessoa do singular- exceto em crônicas ou artigos em tom autoral.

Algumas características saltam aos olhos, especialmente o desenho da página, muito refinado para os textos blocados da época e ainda com poucas ilustrações. Observa-se a presença de oito fotografias acompanhadas de pequenos textos-legenda indicativos: "A sala de redacção", "O escriptorio da rua do Ouvidor" (sede), "Uma das salas das machinas" (gráfica), "A typografia às 8 da noite", "A sahida dos jornaes no edificio da rua Sete", "A Stereotypia" (outro setor da gráfica) e "A nova fachada do escriptorio". 
Para a época, essa disposição é ousada devido ao grande número de fotografias - mais comum nas revistas ilustradas do que em jornais diários. Tal excepcionalidade se explica pelo fato de ser matéria institucional, onde o veículo se apresenta ao leitor ou anunciante como o melhor produto jornalístico na então capital da República. Em suma, o melhor jornal do país. O uso incomum de fotografias imprime sentido explícito: a sacralidade que unge o registro químico da imagem a expressar uma verdade - especialmente quando o assunto é sobre a pujança desse veículo de comunicação. Inevitável lembrar o mote popular "é ver para crer". O texto não verbal conquista a mesma importância que o texto verbal para imprimir sentidos no imaginário do leitor.

A página apresenta quase um círculo de fotografias em sua diagramação. Tal desenho, em somatória ao título, perfaz uma página dinâmica com movimento entre os seus vários elementos, convidando o olhar do leitor não apenas a lê-la, mas a percorrer a sua pulsação como grande conjunto imagético. Pulsação esta que denota dinamismo e agilidade, dois predicados fundamentais do grande paradigma da Modernidade: a tecnologia na era das máquinas. Estes predicados que o jornal assume para si a partir do desenho da página - texto nãoverbal - se confirma no texto verbal da página ao dialogar em fluidez com as imagens. Este é o "jornal moderno”, como a própria Gazeta de Notícias se autoreferencia na matéria.

O texto sinaliza ao leitor que, pela irrisória quantia de 100 réis, é possível especificar o bom tipo de produto a ser adquirido: "é preciso que o typo seja bom, a revisão excellente, haja assumptos palpitantes, chronicas, artigos, um noticiário complettissimo, photogravuras, caricaturas - um mundo". (COMO SE FAZ..., 1907, p.9). A partir destes ingredientes básicos, a matéria indica que:

[...] dos jornaes do Rio de Janeiro, a Gazeta de Notícias é dos que acompanhando o movimento de informação europeu e norteamericano, primeiro nos tem dado e acostumado a todas essas novidades. Foi ella que fez o jornal barato, que iniciou as grandes 
collaborações, a caricatura instantanea, a interview, as enquetes, e até - a informação a cores. Pode-se dizer sem falsa modestia que a Gazeta de Notícias não poupa sacrifícios em bem servir o publico. (COMO SE FAZ..., 1907, p.9).

Este início demonstra a funcionalidade desse texto em convencer o leitor de que a Gazeta de Notícias seria o melhor produto jornalístico da época. Tanto a variedade de temas e de abordagens quanto o uso de cores em suas páginas são destacados como elementos inovadores. Mais uma vez, a tentativa de conciliar duas pujanças: a tecnológica e a comercial, o que é recorrente ao longo deste objeto midiático: "Como se faz um 'jornal moderno'."

O jornal informa que lança mão, todos os dias, do recurso de aumentar o volume de "informação" - sempre esta prioridade como "correspondencias estrangeiras dos Estados, do serviço telegraphico que custa por anno uma fortuna". Neste mesmo plano de custos, inserese a "informação visual" e explica-se que "os photographos apanham o caso sensacional, mandam ao gravador, se junta na redacção a prova [amostragem impressa em papel do clichê gerado] à noticia, enquanto a chapa desce para ser tirado ao bloco". (COMO SE FAZ..., 1907, p.9).

O texto sugere, de forma explícita, que o fotojornalista tem a mesma importância do repórter que colhe dados para que o redator componha o texto verbal da matéria. Ambos se lançam à rua para apanhar o "caso sensacional" e a edição final tem que harmonizar os textos verbal e não verbal para oferecer ao leitor o melhor produto jornalístico.

É bom lembrar que tal reconhecimento de paridade de valor entre esses profissionais não se estabeleceu na grande imprensa por muito tempo. Até há pelo menos 20 anos, era comum na grande imprensa a ostentação de superioridade entre os repórteres/redatores (então funções exercidas por um único jornalista) e os fotojornalistas. Os primeiros gostavam de "brincar" com os focas ou quem não era desse meio profissional quando em visita às redações com o mote "nós trabalhamos com 10 dedos e os lambe-lambes com apenas um". 


\section{Silenciamento e racismo}

Enquanto o jornalismo moderno apresenta-se como um texto da Modernidade tardia que chega ao Brasil, periferia do capitalismo, a reforma urbana se materializa como segundo texto - não-verbal - para instaurá-la entre nós. Em 1857, Paris já impunha o modelo de metrópole moderna, entretanto, somente na primeira década do século XX iniciouse o processo de modernização urbana na então capital federal brasileira.

As transformações urbanas ocorridas durante a reforma pela qual passou o Rio de Janeiro - o chamado "bota-abaixo" - não poderiam passar em branco para a imprensa brasileira, tornando-se um de seus temas principais.

A movimentação da nova urbe brasileira caracterizou-se como um projeto bem próximo ao parisiense, sendo estruturada na busca por um conceito de nação dentro da rota da Modernidade ocidental. Basicamente, esse conceito se sedimentou nos moldes da industrialização que marcha sem parar, aliada à extrema exclusão social das classes subalternas - composta de pobres e/ou negros -, com aspectos especialmente danosos no Brasil, cujas consequências mantêm-se até hoje. Dois grandes braços da Modernidade brasileira são a imprensa e a cidade, cujos textos sobre os quais se inscrevem em nossa sociedade, demarcam a nossa história.

O eixo da reforma deu-se com a avenida Central, hoje Rio Branco, em ruas amplas com vistas a promover o fácil deslocamento de pessoas e de mercadorias. Os antigos casarios usados como insalubres cortiços ou galpões com pequenas fábricas ou comércio foram substituídos por palácios amplos e luxuosos da iniciativa privada ou do governo, a exemplo da Biblioteca Nacional.

Entre as matérias jornalísticas geradas após a inauguração da avenida Central, destacamos como exemplar a publicada pela revista Leitura para todos: magazine mensal illustrado (1907) (Figura 1), na ascendente modalidade de revistas ilustradas que explodiram no início 
do século XX devido aos avanços tecnológicos, especialmente em termos de publicação de fotografias entre outros textos não verbais como ilustrações e charges em geral. Esta é a matéria principal do referido exemplar, intitulada "Através da Avenida" (Figura 2) - não assinada e totalizando 11 páginas. $O$ periódico visava a ser leitura, como o próprio nome indica, para toda a família carioca.

Figura 1 - Página da revista Leitura para todos

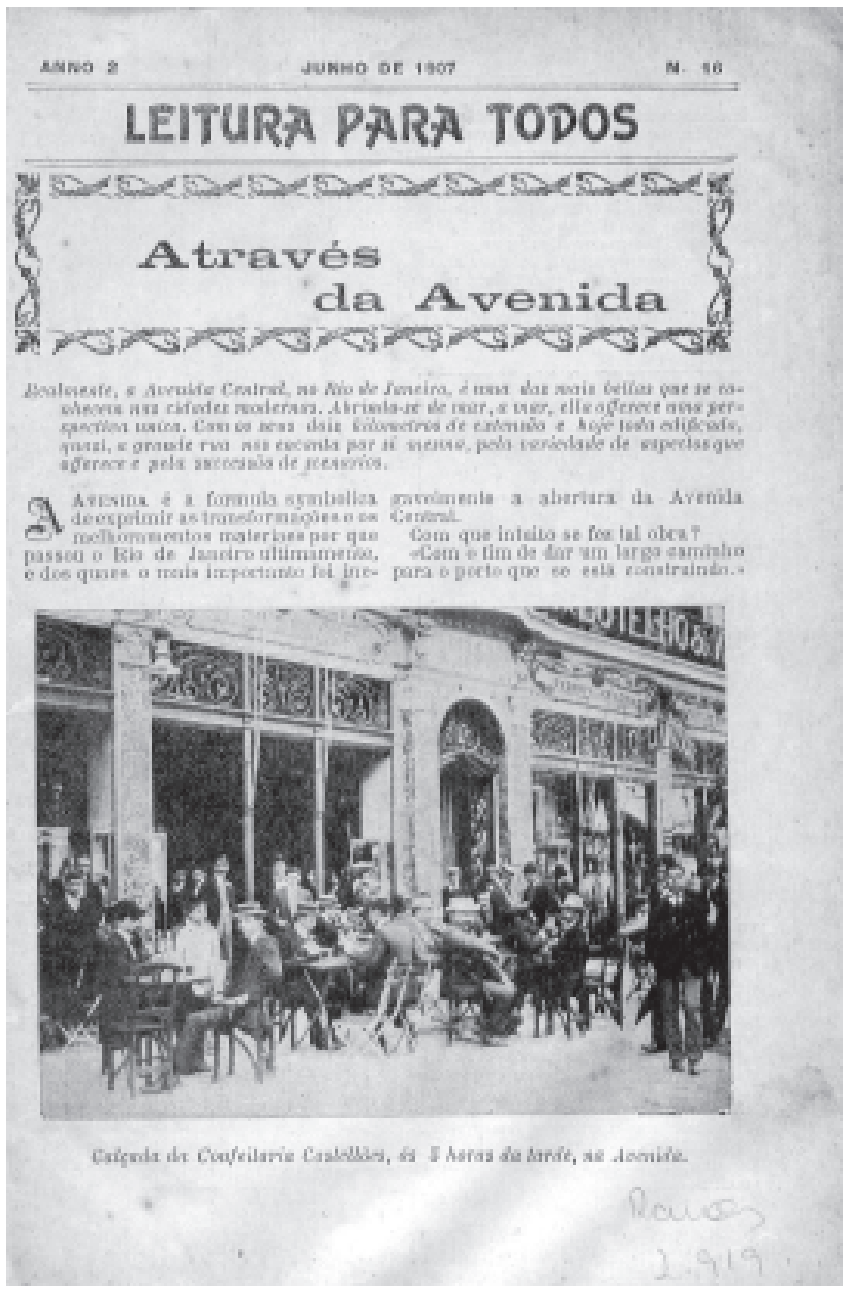

Fonte: Revista Leitura para todos (acervo pessoal do autor) 
Figura 2 - Através da Avenida, página da revista Leitura para todos

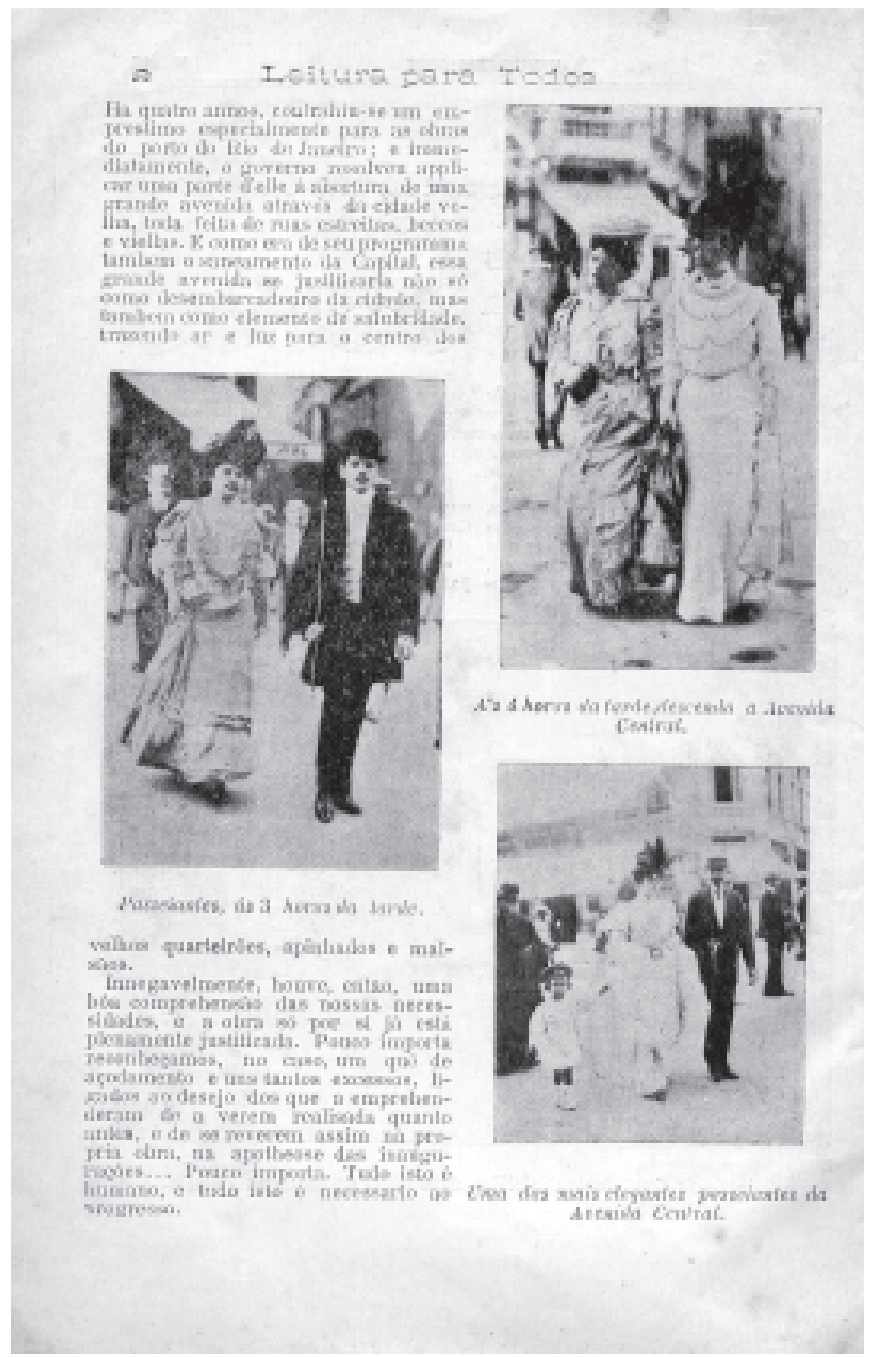

Fonte: Revista Leitura para todos (acervo pessoal do autor)

De início, chama a atenção o fato de que todas as páginas contam com fotografias, constituindo mais da metade do material gerado em relação ao texto verbal. Ou seja, a fotorreportagem ou o mero registro da imagem estática é primordial para esse segmento de objetos midiáticos 
- daí serem chamadas de ilustradas. Nela, as fotografias não estão apenas para dar sustentação ao texto verbal, mas desfrutam, sim, da mesma importância. Percorrer o texto verbal é importante para constatar o diálogo com os instantâneos da avenida Central.

A primeira página é ilustrada com uma fotografia da calçada da Confeitaria Castellões (Figura 1), às 17 horas, um dos principais pontos de encontro da avenida Central. Porém, entre as fotografias, as cenas mais presentes são de passeios na avenida, destacando senhoras e cavalheiros a desfilar em finas vestimentas da última moda conhecida diretamente de Paris (Figura 2), como pudemos apurar nas páginas 2 , 3, 4, 6, 7, 9 e 10. Constatamos que, dos 22 clichês publicados, 12 são dedicados a este tipo de informação imagética.

Isto é, a reportagem fotográfica imprime um espírito prioritário ao novo logradouro, circunscrevendo-o a uma passarela dos segmentos de classe dominante ou dos profissionais liberais incluídos na nova ordem econômica e social brasileira de viés europeu e norte-americano. O texto verbal da matéria segue o mesmo diapasão de forma coerente em um todo editorial.

Composta na primeira pessoa do plural, o primeiro parágrafo da matéria, que funciona como um "olho" em termos atuais - inclusive, com formatação diferenciada em relação ao resto do texto em itálico e em apenas uma coluna em relação às duas colunas do resto da reportagem - informa que a avenida Central é "uma das mais bellas que se conhecem nas cidades modernas".

Atentamos que a noção de beleza é agregada à de Modernidade. Os dois quilômetros de avenida encantam pela "variedade de aspectos que offerece e pela sucessão de scenarios". Assim, localizamos outra marca da Modernidade estabelecida na diversidade de características ao demonstrar este logradouro como se fosse um grande teatro com vários palcos e cenografias próprias. A avenida Central (Figura 3) é, acima de tudo, para ser vista, admirada e desejada. Logo, a sua inflação imagética é derivada desse espírito do tempo. 
Figura 3 - Tomada em plano aberto da avenida Central (provavelmente 1907)

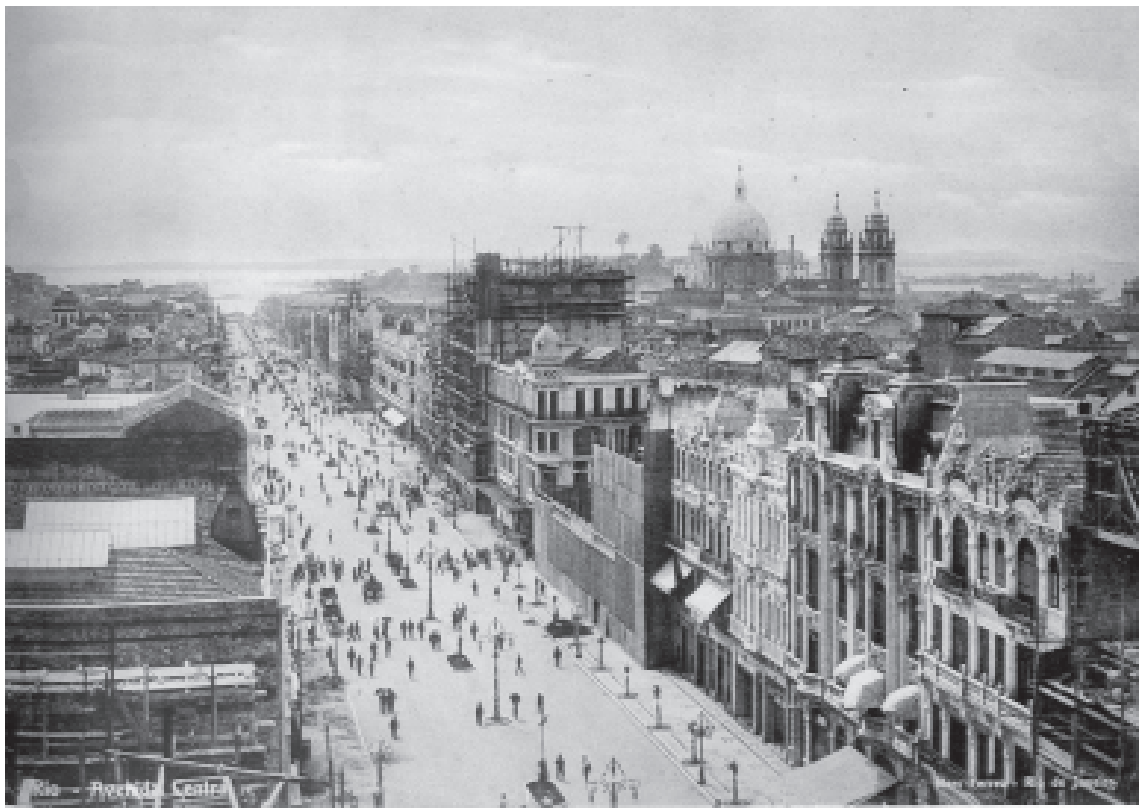

Fotografia: Marc Ferrez

Fonte: Biblioteca Nacional

O primeiro parágrafo da matéria também já estabelece a avenida como a "formula symbolica" que exprime as grandes transformações e "melhoramentos materiaes" da urbe. No parágrafo seguinte, lançase a pergunta: "Com que intuito se fez tal obra?" Em primeiro lugar, como via ampla de acesso à reformulação e ampliação do novo porto. Assume-se que a grande avenida foi necessária para pôr abaixo a cidade velha, feita de "ruas estreitas, beccos e viellas" (Figura 4) e somam-se alusões ao programa de saneamento do governo: "elemento da salubridade, trazendo ar fresco e luz para o centro dos velhos quarteirões, apinhados e malsãos" (Figura 5), o que nos permite constatar o discurso da assepsia urbanística, outra marca da Modernidade. Diante disso, não importam as críticas recebidas, pois "tudo isto é humano, tudo isto é necessario ao progresso". 
Figura 4 - Avenida Central (1905) durante as reformas urbanisticas do início do século $X X$

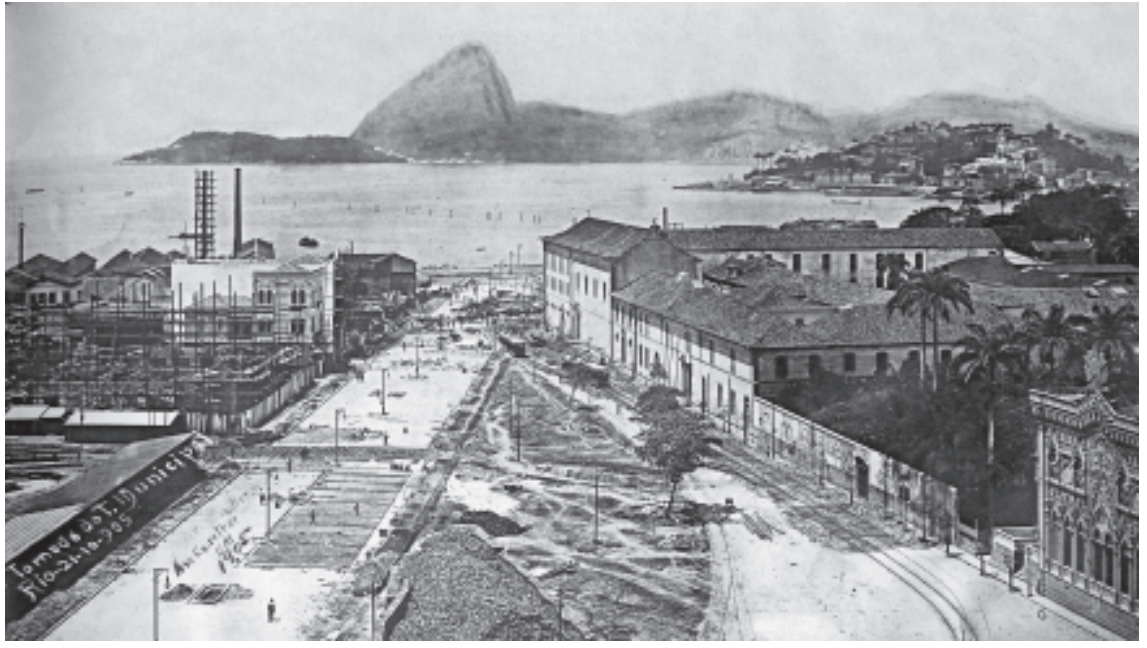

Fotografia: Marc Ferrez

Fonte: Biblioteca Nacional

Figura 5 - Avenida Central depois das reformas urbanisticas do início do século XX

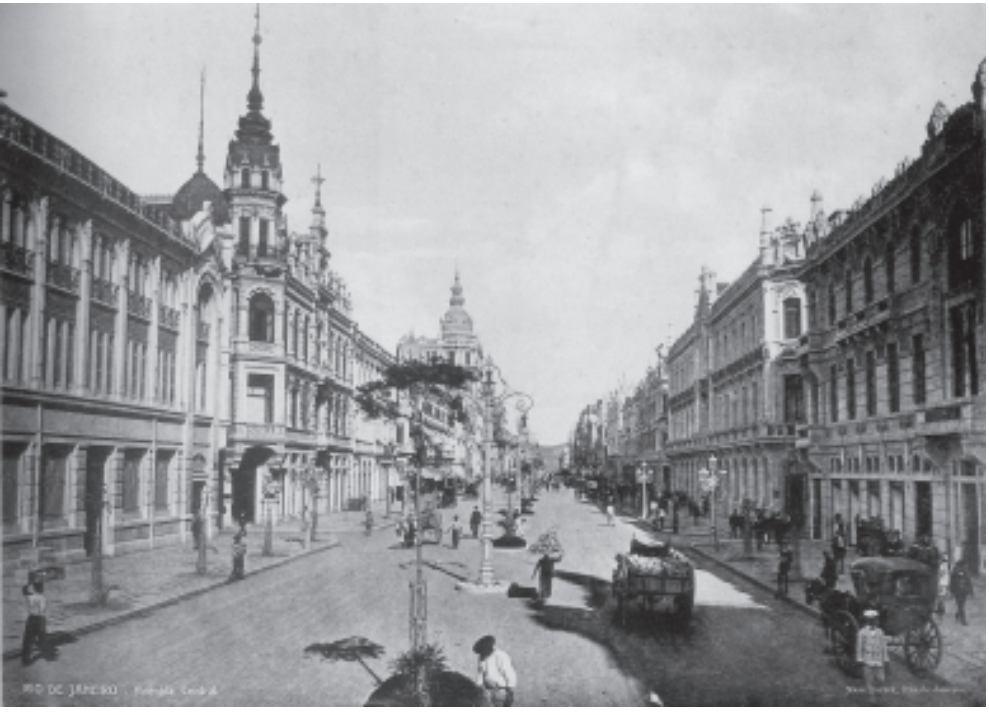

Fotografia: Marc Ferrez

Fonte: Biblioteca Nacional 
A reformulação da capital francesa sob a direção do prefeito Eugène Haussmann foi o modelo implantado no Rio de Janeiro. O programa urbanístico parisiense foi realizado também sob condições políticas similares ao do carioca, sob duro governo ditatorial sob a monarquia restaurada, reagindo amplamente contra as revoltas de 1848, a Comuna de Paris.

Outro aspecto importante está no fato de ser uma fase de convergência tecnológica em vários campos de atividade, devido ao surto de industrialização. O centro de Paris também era composto de ruelas, muitas nada retas, que ofereceram um campo de batalha ideal para as barricadas dos trabalhadores durante a sangrenta Comuna. O plano de Haussmann, de rasgar a cidade com amplas e retas avenidas, visava também evitar o ambiente anterior propício a motins e outras formas de revoltas populares. $^{2}$

Além disso, os bulevares atendiam a razões de ordem sanitária e novas exigências de circulação urbana colocadas pelo desenvolvimento da grande indústria. Ou seja, uma nova ordem urbanística nascia e se tornava modelo para todo o mundo:

Transformados num grande paradigma urbanístico para todas as capitais do mundo, no símbolo maior de seu ingresso na civilização e na modernidade capitalista (as amplas cidades espanholas, as perspektiv de Leningrado, as avenues de Nova York), os bulevares de Paris datavam do século XVII, quando foram abertos no lugar das antigas fortificações, como monumentos arquitetônicos destinados a satisfazer o olhar do promeneur. Haussmann deulhes o caráter de grandes artérias, para atender ao tráfego pesado e articular os principais terminais de articulação da força de trabalho e das mercadorias no centro comercial. (BENCHIMOL, 1990, p.493).

Semelhante movimento de anseio de metropolitização não foi exclusivo do Rio de Janeiro no contexto da América Latina, tal semiosfera

\footnotetext{
2 Já a partir de 1900, o plano de Haussmann era completamente rechaçado pelos arquitetos e urbanistas modernos. Em seu clássico estudo de 1924, Le Corbusier observa que: "Los trazados de Haussmann eran totalmente arbitrarios: eran conclusiones rigurosas de urbanismo. Se trataba de medidas de carácter financiero y militar (cirugía).” (LE CORBUSIER, 1962, p.152).
} 
europeia - campo semiótico de textos verbais e não verbais, na acepção de Iuri Lotman - tomava todos os seus países desde 1880. A vertigem do progresso - mais uma vez esta palavra-chave da Modernidade, como apontou o historiador argentino José Luis Romero - era evidente. As cidades onde mais claramente se viu prosperidade econômica e transformações urbanísticas foram as capitais que eram, ao mesmo tempo, portos: Rio de Janeiro, Montevidéu, Buenos Aires, Panamá, Havana e San Juan de Porto Rico.

Muitas cidades marítimas se modernizaram, as em contato direto com o exterior, verdadeiras correias de transmissão ao atuar como fronteiras na troca de valores e elementos entre o nacional e o internacional. A intensa atividade econômica se desenvolvia em paralelo às sedes políticas e administrativas, que se caracterizam como centros financeiros de seus respectivos países. Fora deste perfil específico, também viraram centros econômicos cidades interioranas, como Caracas e Lima:

El ejemplo del barón de Haussmann y de su impulso demoledor alimentó la decisión de las nuevas burguesías que querían borrar con su pasado, y algunas ciudades comenzaron a transformar su fisonomía: una suntuosa avenida, un parque, un paseo de carruajes, un lujoso teatro, una arquitectura moderna, revelaron esa decisión aun cuando lograran siempre desvanecer el fantasma de la vieja ciudad. Pero las burguesías podían alimentar sus ilusiones encerrándose en los ambientes sofisticados de un club hermético o un restaurant de lujo. Allí se participaban los pasos que transmutarían a "la gran aldea" en una moderna metrópoli. (ROMERO, 1976, p.249).

Um dos principais momentos da matéria surge na terceira página, quando se afirma que o governo não pensou, mas aconteceram transformações de forma rápida e radical nos costumes fluminenses. Destaca-se que nada parecido teria acontecido anteriormente, mudando não apenas o "aspecto physico" da sociedade, mas atingido principalmente "a sua physionomia moral". Aqui destacamos essa metáfora imagética da fisionomia, do rosto, presente em toda a matéria. Em suma, a Modernidade 
é, acima de tudo, um movimento que prima pelas imagens estáticas ou em movimento. Daí seus diletos filhos serem o cinema e a fotografia.

A partir dessa afirmação, a matéria entra em extensa digressão sobre a adaptabilidade do homem à natureza, quando não a transforma conforme os seus interesses, outra marca importante da Modernidade. Em seguida, retoma-se a afirmação de que não há notícia de tão grande transformação ocorrida em uma urbe. A imediata adaptação do carioca à nova realidade seria "a melhor prova que se póde tirar da nossa capacidade de progresso, porque o progresso não é mais que uma serie de adaptações successivas. Quanto mais adaptavel, mais progressista é um povo", sentencia.

O discurso da Modernidade e do progresso continua a ser tecido pela matéria ao declarar que, anteriormente, era "uma vida primitiva, elementar, acanhada - numa cidade acanhada, rudimentar, primitiva". Em resposta ao atraso, surge a "cidade moderna" com ruas "largas, bellas" - mais um momento de redundância para fixar os mesmos conceitos da Modernidade através do texto não-verbal urbano. As ruas amplas também trazem a possibilidade do trânsito dos automóveis fetiche da máquina - e os cafés.

Os cafés transbordam para as calçadas e "os desoccupados resolveram passeiar, e o centro da cidade tornou-se de um nunca visto movimento de gentes chics". É interessante observar a ligação entre os desocupados e os "chics", pois lembra a parte substancial dos brancos do Rio de Janeiro que não trabalhava para seu sustento durante a Monarquia, sendo mantidos pelos chamados "negros de renda". Pode-se pensar que a República manteve traços substanciais da Monarquia, em paradoxo completo com sua constituição original.

A matéria prossegue fazendo a devida marcação geográfica dos segmentos de classe dominante. Antes, quando se falava em Rio de Janeiro pensava-se logo em rua do Ouvidor. Ela informa que em 20 anos, de 1870 a 1890, a "cidade duplicou de importancia, de população e commercio, mas continua a ser viella, sem gosto, sem espaço, sem horizonte... rua estreita, onde se comprimiam, quietos todos, os fluminenses". 
Entre várias passagens deste texto, verificamos como o teor informativo realmente emergiu no jornalismo moderno. Por exemplo, argumenta-se que o "Rio de Janeiro de um milhão de habitantes tinha o mesmo local de rendez-vous que o Rio de Janeiro de 300.00 mil [sic] habitantes - a Rua do Ouvidor". (ATRAVÉS..., 1907, p.7). Depreendese que os trabalhadores voltavam rapidamente para casa ou os que nela estavam não saíam, por absoluta falta de opção de lazer.

Após a abertura da avenida Central e do alargamento da ruas Uruguayana, Sete de Setembro, Assembléa, Carioca e São Joaquim, há o fluxo de uma "massa de gente" em trânsito que não comportaria a rua do Ouvidor. Entre outras formas para desqualificar a antiga rua, expõe-se como a mulher começa a ocupar o espaço público, importante quesito de comportamento contemporâneo:

\begin{abstract}
Deram-lhe ar, luz, elegância, e a possibilidade de uma vida realmente urbana. As senhoras já pódem sahir e vagar pelo centro da cidade, sem o desgosto de atravessar a via-sacra da rua do Ouvidor, roçando, de um extremo ao outro, pelos braços e pelas pernas dos malcriados e bolinas que, com esse intuito, alli se apinhavam; os homens que desejavam ver o mundo, e têm prazer de contemplar de porto a actividade e a novidade, já pódem estar na rua sem a necessidade de se converterem em estafermos, parados pelas portas. (ATRAVÉS..., 1907, p.9).
\end{abstract}

Segundo a matéria, o novo traçado urbanístico provocou uma assepsia moral para que a mulher pudesse transitar pelo espaço público com segurança similar ao do espaço privado. Esta é outra marca da Modernidade que assoma na época, pois anteriormente a mulher das classes mais privilegiadas estava confinada ao espaço privado da moradia. Só poderia se locomover pelo espaço público acompanhada por um homem - especificamente pai, irmão ou marido - ou na companhia de outra mulher, esta uma "senhora de respeito". Outro ícone é agregado ao espaço urbano remodelado por completo: o automóvel. Ou seja, a possibilidade de rápido deslocamento no espaço urbano: "Estar na cidade, jantar em casa, refazer a toillete, voltar à cidade [...].” (ATRAVÉS..., 1907, p.9). 
Após focalizar a dimensão urbanística das reformas, a matéria se centra na arquitetura. Quem passa pela avenida Central, tem "innegavelmente a impressão" de estar em uma grande cidade: "A variedade de stylo, nas construccções, dá-lhe uma belleza [mais uma vez, a reincidência do belo ligado à Modernidade] e um encanto não comuns nas suas congêneres." Os edifícios de grandes proporções são destacados, e também os "ridiculamente pretenciosos". Com isso, determina-se que a diversidade se expressa "em deliciosa successão de aspectos". (ATRAVÉS..., 1907, p.10-11).

Por último, a matéria justifica o seu título de passeio pela avenida ao apontar os principais pontos de atração pública: a calçada em frente ao convento da Ajuda e os seus os "passeiantes desoccupados", a estação do Jardim Botânico, o “canto” (esquina) da rua São José onde se localizava o primeiro café da nova avenida, a rua da Assembléa onde ficava o Café Frontin e a parada de automóveis. Além da Confeitaria Castellões - cuja fachada é o tema da primeira fotografia da matéria - por ser a primeira "que levou mesas ao passeio" e único lugar do logradouro onde se vê grupos parados.

Em suma, este "nós" sobre o qual é construída a matéria são os segmentos da sociedade mais privilegiados - no mínimo, a partir de classe média. Ressaltamos que seu ápice incide na questão feminina, apesar de se dirigir e ser de interesse da família como um todo. A partir disso, compreendemos que a verdadeira "pauta" é como a mulher pode sair às ruas e assumir um lugar no espaço público, apesar de limitado. O que já seria um avanço considerável em relação aos costumes do Rio de Janeiro antigo, quando a mulher deveria ser encerrada no espaço privado-exceto as "mal-nascidas", cujo sustento deveria ser buscado fora de casa.

E aqui a profusão de senhoras e esmeradas roupas e acessórios parisienses cumpre o papel de sacralidade do fotojornalismo. A imagem da mulher na rua - ora sozinha ora acompanhada por um homem - é um grande "furo" jornalístico de radical mudança nessa sociedade.

Consideramos este momento como o ápice da matéria por dialogar diretamente com o texto não-verbal da fotorreportagem, pois os instantâneos expressam senhoras com finas toilletes a passear pelas ruas 
do novo centro da capital. Aqui localizamos um elemento bem presente em toda a matéria pelo não dito, mas sabido na época - o recurso da pressuposição, amplamente utilizado nos meios de comunicação.

No velho centro da cidade, seus mais presentes ocupantes eram os negros e mulatos pobres que lá trabalhavam e moravam. Com o "botaabaixo", essa população foi expulsa e o logradouro passou por uma "assepsia" racista e classista. Logo, o que este trecho também comunicava às mulheres e seus homens bem postos economicamente é que podiam percorrer esse novo espaço urbano sem o risco de conviver com negros e pobres. Isto não estava escrito, seja com palavras ou imagens, mas podia ser perfeitamente compreendido pelos leitores.

A fotografia que encerra a matéria tem uma dimensão bem específica pressuposta ao leitor da época, já que se vivia a era dos cafés e das confeitarias herdadas da rua do Ouvidor, mas migrados para a avenida Central. Anova urbe, enquanto texto não-verbal da Modernidade, também se expressa como paradigma entre jornalistas e escritores:

A abertura da Avenida Central veio deslocar, em parte, os pequenos grupos que se formavam, à tarde, em diferentes pontos da Rua do Ouvidor; e o sistema de expedientes em que repousa a subsistência dos chamados boêmios, sofria com isso grande golpe. (BROCA, 1960,p.7).

O processo do fim da geração boêmia, que muito animou o jornalismo brasileiro, a exemplo do europeu, dá-se a partir do princípio de profissionalização dos escritores e jornalistas com a fundação da Academia Brasileira de Letras, em 1896. Entre os que se "aburguesaram", segundo o historiador e crítico literário Brito Broca, estavam Aluísio de Azevedo e Olavo Bilac. A nova geração surge em moldes distintos, não mais como "artista morto de fome" disposto a se sacrificar por um ideal estético.

A polaridade aqui é a mesma sentida e reportada pela matéria acima em relação às damas e aos cavalheiros: "Nas amplas perspectivas da Avenida Central os boêmios inveterados já não desfrutavam o prestígio que os cercava nos estreitos limites da Rua do Ouvidor." 
(BROCA, 1960, p.33). Para os boêmios, os “cafés literários" eram o grande palco para a exposição e os encontros com seus pares. Neste sentido, o Café Rio era o principal, localizado na esquina da rua do Ouvidor com a rua Gonçalves Dias, seguido do Java (Largo de São Francisco, esquina com a rua do Ouvidor), Café Paris, Café Papagaio (especialmente frequentado por Lima Barreto) e Café Globo (Rua Primeiro de Março entre a rua do Ouvidor e o Beco dos Barbeiros). Outros pontos disputados da boêmia literária foram as confeitarias Colombo (Rua Gonçalves Dias), Paschoal (Rua do Ouvidor), Cailteau e Castelões - justamente a da fotografia da matéria. (BROCA, 1960).

Porém, uma grande revelação dessa matéria ao público leitor da época - corroborada pelos textos verbais e não verbais - está em um silenciamento ou apagamento de uma grande parcela da população formada de negros ou mulatos e pobres. Eles antes eram os habitantes desse centro da cidade a trabalhar em "bicos" como comércio informal ou no comércio formal ou nas pequenas fábricas que lá pululavam. E lá mesmo moravam em moradias coletivas de péssimas condições, especialmente higiênicas. Essa população foi simplesmente expulsa da região em verdadeiro movimento de "assepsia" classista e daí deu-se a grande ocupação dos morros e subúrbios.

A construção da avenida Central foi conseguida "às custas do despejo sumário de 20 mil pessoas e a derrubada de quase dois mil imóveis". (RODRIGUES, 1996, p.43). Desta forma, buscou-se a invisibilidade das classes subalternas, deslocando-as para os subúrbios ou para os morros. Semelhante acontecimento, posicionando a então nascente República como um sistema de governo do povo para povo, resultou em uma fábrica de exclusão social e consolidou-se como ponto importante da história da modernização do país.

Em 2007, mais de 100 anos depois, o filme Tropa de Elite ${ }^{3}$ - um diagnóstico sobre a "guerra civil" que assola o Brasil, a partir do caso do Rio de Janeiro, onde o crime organizado ocupou a ausência do estado nos morros e subúrbios, em processo que demandou cerca de 30 anos,

\footnotetext{
${ }^{3}$ Direção de José Padilha, baseado na ficção Elite da tropa, de Rodrigo Pimentel.
} 
estabeleceu a situação de extrema violência urbana nas grandes cidades do país.

Toda essa realidade está exposta em regime de "pressuposição", em um entorno de sentidos e discursos que são compartilhados entre a revista e seu público leitor, composto das alas mais privilegiadas da sociedade. Pressuposição essa contextual presente em qualquer diálogo ou troca de enunciados, como explicita o teórico russo Mikhail Bakhtin.

Neste sentido, todo material jornalístico deve ser visto pelo o que expõe e, especialmente, pelo que não expõe ou silencia ou pressupõe. Faz-se necessário uma verdadeira arqueologia de sentidos e de vozes do tempo em que o material de estudo emerge para melhor compreendê-lo e, aí sim, tê-lo como útil material primário para a construção de uma memória social e de um discurso historiográfico.

\section{Documento da realidade}

João do Rio (1881-1921) privilegiou a fotografia como um dos ápices do discurso jornalístico na implantação do moderno jornalismo em sua produção midiática, especialmente na crônica “O jovem carioca”. Para Joe, seu pseudônimo na coluna Pall-Mall Rio, onde está inserido este texto de 1916, há várias formas para "fazer a história de uma geração" como as tendências morais ou a análise das ideias. Porém, a preferência do cronista está na imagem das roupas e dos costumes: "Prefiro a photographia, não só porque está muito na moda, como é documento do que realmente existe." (RIO, 1917, p.107).

Entretanto, na crônica "Clic! Clic! Photographo", também em Pall-Mall Rio, o cronista mundano localiza o feérico da inflação da atividade que dá título ao texto. Uma senhora em plena avenida Central, a passarela das elegantes, tenta driblar um fotógrafo posicionado com "o kodack" em punho. Ele pede licença, diz que a chapa é para uma revista ilustrada. Até que ela concorda e "ficou de pé, numa pose de ave real, sorrindo, enquanto o moço louro de novo kodackizava". (RIO, 
1917, p.212-213). Ou seja, a madame em questão quer ser fotografada, a tentativa de fuga foi um mascaramento de suas intenções verdadeiras, um pequeno cabotinismo na vida cotidiana. Além disso, verifica-se a presença de personificação designando a condição de ação para um produto, no caso, o nome de um dos maiores fabricantes no lugar de câmeras fotográficas. Na sequência, o jornalista diagnostica esta nova realidade também em outros pontos da cidade:

[...] nós temos agora mais um exagero, mais uma doença nervosa: a da informação photographica, a da reportagem photographica, a do dilettantismo photographico, a da exhibição photographica - a loucura photographica. [...] não ha propriamente pessoas notaveis cuja physionomia faça necessidade informativa dos jornaes porque não ha cara que não seja publicada. (RIO, 1917, p.213).

Entre os aspectos simbólicos do tempo que se encontram neste trecho, está o discurso cientificista a partir do uso da psicologia, ao categorizar a inflação de fotografias como uma “doença nervosa”. Há, ainda, a repetição obsessiva do termo "photographica", completamente não usual em João do Rio. Este recurso estilístico expressa, na materialidade do texto, a constância do gesto de clicar que está sendo localizado na sociedade. Por último, o jornalista aponta o resultado desse processo inflacionário, o desvalor das imagens clicadas, pois, conforme afirma, os rostos possíveis ou relevantes já foram enquadrados.

No final da vida, João do Rio (Figuras 6 e 7) elaborou algumas reflexões bem objetivas sobre os rumos tomados pela imprensa moderna que muito se aproximam às de Lima Barreto, tirante o tom editorializante que este último assumiu. Em "O segundo Olavo Bilac", João do Rio aponta que a "história dos nossos costumes" terá sempre uma falha nesta primeira década (do século XX), na brusca transição entre a "forma burguesa lusitana" para a "atoarda [notícia imprecisa, boato] assaltante norteamericana", a documentação sobre a imprensa. Para ele, não houve um observador imparcial para construir essa narrativa memorialística, pois a “a imprensa impressiona tôdas as classes, o mêdo do seu poder destruidor 
é tremendo nos que dela fazem parte". Isso João do Rio declarou, é bom lembrar, quando era dono de jornal.

Figura 6 - Caricatura do jornalista e escritor João do Rio

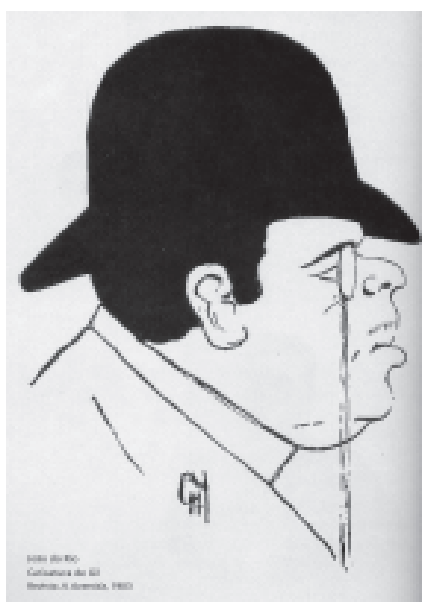

Autor: Gil

Fonte: Revista A Avenida (1903) (acervo pessoal do autor)

Figura 7 - Fotografia do jornalista e escritor João do Rio

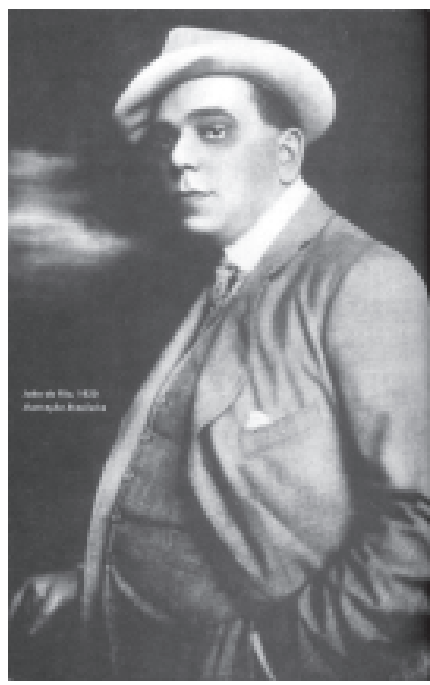

Fotografia: Revista Ilustração Brasileira

Fonte: Revista Ilustração Brasileira (acervo pessoal do autor) 
O cronista lembra que, no primeiro momento da "transformação yankee", os literatos deixaram a direção de jornais para serem assuntos dos mesmos. Uma das primeiras consequências disto foi o "rompimento do dique do respeito, as hierarquias mentais desapareceram" (RIO, 1917, p.179) para dar lugar ao império da publicidade. Apesar de enunciar as coisas quase como um indiano em sua estanque sociedade de castas, elabora o fim da reflexão e o detrimento da informação.

Como consequência, se o escritor não for amigo dos donos de jornais "qualquer energúmeno pode atacar os autores dessa lança sem raízes - a arte". Já o noticiário de louvores "é feito em camaradagem e sem a leitura das obras de que fala". (RIO, 1917, p.180). Mais uma vez, João do Rio insiste que o diapasão da imprensa é atacar ou defender, mas deixa mais evidente o que seria o jogo de interesses vários.

\section{Considerações finais}

Como definiu um dos maiores historiadores latino-americanos, o argentino José Luis Romero, a história não serve apenas para contar o que aconteceu, mas para compreender o que vivemos hoje e colaborar com a nossa postura em relação ao futuro. Ouvir estas e outras vozes da época, como percorremos aqui, é importante para construir uma memória obliterada sobre o jornalismo do começo do século XX e o destino dos veículos de comunicação para melhor pensar esta realidade hoje e tentar projetar o futuro.

Logo, acreditamos que foi possível levantar questões acerca de aspectos do fotojornalismo e da história, com vistas à construção da memória, explicitamente em busca de um tempo revelado pelo processo químico da escrita com a luz (photo + graphia). Faz-se cada vez mais necessária uma arqueologia textual verbal ou não verbal para a reconstituição de construções de sentidos impressas em jornais ou revistas ilustradas. 
Pois, entre outros predicados desses objetos midiáticos, conseguiuse alcançar uma dimensão de extrema importância da fotografia no nascedouro dos meios de comunicação de massa no Brasil. Fundamental não apenas para o segmento jornalístico, mas para os mais diversos campos de atuação e de pensamento.

\section{Referências}

ATRAVÉS da avenida. Leitura para todos. Rio de Janeiro, ano 2, n.16, jun. 1907. p.1-11.

BAUDELAIRE, Charles. O pintor na vida moderna. In:

A invenção da modernidade: sobre arte, literatura e música. Tradução de Pedro Tamen. Lisboa: Relógio D’Água, 2006.

BENCHIMOL, Jaime Larry. Pereira Passos, um Haussmann tropical: a renovação urbana na cidade do Rio de Janeiro no início do século XX. Rio de Janeiro: Secretaria Municipal de Cultura, Turismo e Esportes, 1990.

BROCA, Brito. A vida literária no Brasil 1900. Rio de Janeiro: José Olympio, 1960.

COMO se faz um jornal de hoje. Gazeta de Notícias, Rio de Janeiro, 2 ago. 1907.

LE CORBUSIER. La ciudad del futuro. Buenos Aires: Infinito, 1962.

LEFEBVRE, Henri. Introdução à modernidade. Tradução de Jehovanira Chrysóstomo de Souza. Rio de Janeiro: Paz e Terra, 1969. 
LOTMAN, Iuri. La semiosfera. Madrid: Cátedra, 1996.

LOURENÇO, Jorge Fazenda. Introdução. In: BAUDELAIRE, Charles. A invenção da modernidade: sobre arte, literatura e música. Tradução de Pedro Tamen. Lisboa: Relógio D’Água, 2006.

MEDEIROS, Gutemberg Araújo. Urbanidade e metajornalismo nas matrizes da modernidade: memória textual nas produções de Lima Barreto e João do Rio no início do século XX. 2009. Tese (Doutorado em Ciências da Comunicação) - Escola de Comunicações e Artes, Universidade de São Paulo.

RIO, João do. Pall-Mall Rio: o inverno mundano de 1916. Rio de Janeiro: Villas-Boas, 1917.

RODRIGUES, João Carlos. João do Rio: uma biografia. Rio de Janeiro: Topbooks, 1996.

ROMERO, José Luis. Lationoamérica: las ciudades y las ideas. Mexico: Siglo Veintiuno, 1976. 